\title{
Influence of Bacopa monnieri in suppressing the arthritis induced by MSU crystal in Wistar albino female rats: Through biochemical and histopathological approach
}

Jerine Peter Simon ${ }^{1}$, Prajakta Subhash Gaopande ${ }^{1}$, Swathika Praveen ${ }^{1}$, Arjun Ajikumar Reeja ${ }^{1}$, Abinaya Rajasekar ${ }^{1}$, Radhakrishnan Vidya ${ }^{2}$, Usha Kumari ${ }^{3}$, Evan Prince Sabina ${ }^{1 *}$.

${ }^{1}$ Department of Biomedical Sciences, School of Biosciences and Technology (SBST), VIT, Vellore, India.

${ }^{2}$ VIT School of Agricultural Innovations and Advanced Learning (VAIAL), VIT, Vellore, India.

${ }^{3}$ Department of Physiology, Faculty of Medicine, AIMST University, Bedong, Malayasia.

\begin{tabular}{l}
\hline ARTICLE INFO \\
\hline Received on: $22 / 05 / 2019$ \\
Accepted on: $21 / 08 / 2019$ \\
Available online: $05 / 10 / 2019$
\end{tabular}

\section{Key words:}

Gouty arthritis, Bacopa monnieri, monosodium urate crystal, indomethacin, anti-arthritis.

\begin{abstract}
Gouty arthritis is caused due to the accumulation of uric acid crystals in joints which is the by-product of purine metabolism in our body. The elevated level of uric acid in the blood is known as hyperuricemia that may results in deposition and inflammation of joints. This research experiment has examined the protective effect of Bacopa monnieri, an herb against the monosodium urate crystal-induced gouty arthritis in female Wistar albino rats. The rats were divided into four groups with six rats in each group. Group-I was normal control rats, group-II rats were induced with monosodium urate crystal, group-III was administrated with B. monnieri in monosodium urate crystal-induced rats, and group-IV was administrated with indomethacin in monosodium urate crystal-induced rats. The rats were examined for liver enzyme markers, antioxidant assays, and paw histopathology. The results of $B$. monnieri were compared with that of standard drug indomethacin. The symptoms of arthritis, such as the elevation of paw volume, increased liver enzyme markers, decreased antioxidant enzymes, and histopathological changes, were found to be reversed to the normal level by the treatment with $B$. monnieri which is due to its anti-inflammatory properties. As conclusion, B. monnieri has shown its anti-arthritic properties against gouty arthritis.
\end{abstract}

\section{INTRODUCTION}

Bacopa monnieri is also known as Herpestis monniera, locally popular as Brahmi or Jalanimba in India. It is widely treasured as the modernized herb that was used by Ayurvedic medical practitioners for about 3,000 years (Mukherjee and Dey, 1966). The herb is found all over the Indian subcontinent in watery and swampy places (Nadkarni and Nadkarni, 1976). For centuries, the herb has been used in Ayurvedic medical system as a sensory organ replenisher, brain and cardiotonic, enhancing memory power, and as antiepileptic drugs and an antidepressant ('Bacopa monniera.

\footnotetext{
${ }^{*}$ Corresponding Author

Department of Biomedical Sciences, School of Biosciences and Technology (SBST), VIT, Vellore, India.

E-mail:eps674@gmail.com
}

Monograph', 2004; Chopra et al., 1956). The nootropic functions of Bacopa has been described and studied extensively on memory and cognition (Kongkeaw et al., 2014; Neale et al., 2013). The main compounds that are responsible for the pharmacological effects of the herb include sterols, saponins, and alkaloids, while other alkaloids like nicotine and herpestine have been reported (Chopra et al., 1956; Dhawan, 2015). It has been found that the main chemical compound responsible for neuropharmacological effects, cognitive enhancement, and antiamnestic effect of the herb is bacoside A, assigned as 3-(a-L-arabinopyranosyl)-O-b-D-glucopyranoside-10, 20-dihydroxy-16-keto-dammar-24-ene (Gubbannavar et al., 2013).

Gout is a disease caused by the reduction in uric acid excretion due to disorder in purine metabolism which is induced either by acquired or genetic factors. Excess uric acid in the blood, deformities in the joints, and chronic gouty arthritis are the medical characteristics of gout. With the developing living standards, the predominance of this disease has developed gradually 
(Chilappa et al., 2010). Gouty arthritis (GA) is a painful condition due to crystallization of urate in joints and soft tissue, resulting in the elevation of uric acid in the body (Bhansing et al., 2010). About 8.3 million of older men and women were estimated to have been affected in USA (Zhu et al., 2011). GA if left untreated, leads to a chronic stage characterized by continuous inflammation and visible monosodium urate (MSU) accumulation known as tophi, resulting in permanent damage of the joints, erosion in bone, and significant disability (Doherty et al., 2012; Richette and Bardin, 2010). The management of GA is to prevent new crystal formation and to dissolve the existing crystal, which is attained by using urate-lowering therapy aimed for keeping up the serum uric acid below the saturation point for MSU. The manifestations are controlled by using anti-inflammatory therapy, including nonsteroidal anti-inflammatory drugs (NSAIDs), corticosteroids, and colchicine (Zhang et al., 2006). Although these drugs are effective, many patients with GA are found to have disorders due to GA medications and correlated contraindications to the regularly available medications (Chuang et al., 2011; Keenan et al., 2011). It has also been found that some patients fail to respond and/or are incompliant to the available standard anti-inflammatory treatment leading to the complexity of maintaining gouty flares. "Difficult to treat" GA are those patients with repeated gouty flares for whom colchicines, NSAIDS and corticosteroids cannot be used for the treatment (Neogi, 2010; So et al., 2010; Schlesinger, 2011). GA initially is the periodic chapters for men as monoarticular arthritis and in women as oligoarticular arthritis in post menopause and subsequent flares in men. In men, monoarticular arthritis and in female, oligoarticular arthritis are commonly known GA. The frequency and severity of flares may increase if left untreated (Hoffmeister et al., 2014; So et al., 2010; Schlesinger et al., 2011). The rising predominance of GA is because of the increased established risk factors, such as the use of diuretics and cyclosporine, conditions such as hypertension and diabetes (Klemp et al., 1997; Roubenoff et al., 1991; Tykarski, 1991; Zaka and Williams, 2006). The best dependable diagnostic criterion for GA is the presence of double refraction. In the synovial fluid of the joint, needle-shaped urate crystals were observed when viewed under a polarizing microscope; the clinicians are unwilling to perform these diagnostic criteria as a joint puncture; therefore, the proper clinical diagnosis is by imaging procedures. In order to detect the joint effusion, increased cell number, bone and soft tissue lesions high-frequency ultrasound is used (Chowalloor and Keen, 2013; Zhang et al., 2018). The search for better drug in treating arthritis without side effect had paved a way to assess the herbal plant in finding its effectiveness as an anti-inflammatory agent. Therefore, the aim of the study is to analyze the effect of $B$. monnieri in treating the arthritis induced by MSU in female Wistar albino rats.

\section{MATERIALS AND METHODS}

\section{Animals}

Albino Wister female rats weighing approximately 150-200 g were obtained from the Animal house, VIT, Vellore, Tamil Nadu, India. These rats were maintained under, humiditycontrolled room with 12 hours of light and 12 hours of dark cycles at temperature of $30^{\circ} \mathrm{C}-35^{\circ} \mathrm{C}$. The rats were randomly taken and divided into control and experimental groups and provided with normal standard diet and maintained in different cages. Animals utilized as a part of this study were dealt with and watched over as per the rules prescribed by the Committee for the purpose of Control and Supervision of Experiments on Animals (CPCSEA), Ministry of Culture, Government of India, and (CPCSEA) Tamil Nadu, Chennai. The Institutional animal ethical committee VIT affirmed the test convention followed in this study (VIT/ IAEC/10th/March 14th/No.22). The research work on the animal model was carried out in VIT animal house and the total duration of animal study is 3 days

Drug: The commercially available B. monnieri (dry powder) was purchased from Himalayan Drug Company, Bangalore, India. Fifty grams of $B$. monnieri was dissolved in $100 \mathrm{ml}$ of distilled water and vortexed for 10 minutes and process was repeated three times before use. $0.5 \mathrm{ml}$ of a drug was orally administrated after 1 hour of incorporating the test animals with MSU crystals in their paw.

\section{Preparation of MSU crystal}

Four grams of uric acid was dissolved in $800 \mathrm{ml}$ of water and $\mathrm{pH}$ was adjusted to 8.9 using $0.5 \mathrm{~N} \mathrm{NaOH}$. The solution was heated at $60^{\circ} \mathrm{C}$ and cooled overnight in a cold room at $4^{\circ} \mathrm{C}$, then it was washed and dried. Needle-like MSU crystals obtained were examined under the microscope and suspended in clean saline at a concentration at $20 \mathrm{mg} / \mathrm{ml}$.

\section{Indomethacin (positive control)}

Indomethacin was purchased from Tamilnadu Dadha Pharmaceuticals Ltd., Chennai, India. It was dissolved in $2 \%$ gum acacia solution and orally administrated at the dosage of $3 \mathrm{mg} /$ $\mathrm{kg} / \mathrm{b}$.wt after 1 hour infusion of MSU crystal. It was repeated for 3 days.

\section{Monosodium urate crystal-induced inflammation in rats}

The animals were divided in following four groups:

Group I: Normal control (2 $\mathrm{ml}$ of sterile saline was injected intraperitoneally)

Group II: $0.2 \mathrm{ml}$ ( $4 \mathrm{mg}$ ) of MSU crystal was administrated intradermally at right foot, inflammation was induced (body yellow).

Group III: MSU crystal-induced rats were orally administrated with $0.5 \mathrm{ml} / \mathrm{kg} / \mathrm{b}$.wt and $B$. monnieri for 3 days

Group IV: MSU crystal-induced rats were orally administrated with $3 \mathrm{mg} / \mathrm{kg} / \mathrm{b}$.wt indomethacin for 3 days.

The separate rat groups were treated orally with $B$. monnieri and indomethacin for 3 days and after completion of each 24 hours, the weight of the rats and the swelling of the rat's leg were checked and noted.

\section{Examination of paw inflammation}

For the evaluation of paw inflammation, the thickness of the paw was measured using Vernier caliber and measurement was taken every 24 hours within interval of 3 days. 


\section{Tissue collection and homogenate preparation}

At the end of 72 hours, the rats were given chloroform (anesthesia) and sacrificed by euthanasia. The liver, spleen, and kidney were removed from all the rats and homogenate were prepared using homogenizer. Blood from all the rats was collected and serum was isolated for all the biochemical studies. The tissue homogenate of liver, spleen, and kidney were used for assaying liver enzyme marker levels, antioxidant enzyme levels, histopathology of skin and bone.

Effect of B. monnieri on antioxidant enzymes of MSU crystal induced gouty arthritis rats

Superoxide dismutase (SOD) activity was tested using the protocol followed by Marklund and Marklund (1974). SOD is a first-line defense antioxidant and this will act and prevent the generation of free radicals in cells. Catalyst test was proceeded based on a standardized method by Sinha (1972) and catalase activity was measured.

\section{Effect of B. monnieri on Lipid peroxidation of MSU crystal induced gouty arthritis rats}

Lipid peroxidation (LPO) activity was measured using Ledwozyw's method ( 1986). Lipid peroxidation is the oxidative degradation of lipids. This process will cause cell damage by taking electrons from lipids in the cell membrane.

\section{Effect of B. monnieri on Liver enzyme markers of MSU crystal induced gouty arthritis rats}

ALT (Alanine transaminase) is a transaminase enzyme. It is also called as ALT (Alanine aminotransferase) and serum glutamate-pyruvate or pyruvic transaminase. ALT catalyzes the transfer of an amino group from L-alanine to $\alpha$-ketoglutarate, the products of this reversible transamination reaction being pyruvate and L-glutamate and is mostly found in liver. AST (Aspartate transaminase) is apyridoxal phosphatedependent transaminase enzyme. It is also called aspartate aminotransferase and serum glutamic oxaloacetic transaminase. AST catalyzes the transfer of amino group between L-Aspartate and $\alpha$ Ketoglutrate to form Oxaloacetate and Glutamate and found in the liver, heart, skeletal muscle, kidneys, brain, and RBC.
ALP (alkaline Phosphatase) hydrolysis p-Nitrophenly phosphate to form $\mathrm{p}$-Nitrophenol and phosphate. The rate of formation of $\mathrm{p}$-Nitrophenol is measured as an increase in absorbance which is proportional to ALP activity in the sample.

\section{Histopathological examinations}

The Portion of the ankles was dissected soon after sacrificing the rats and washed with phosphate buffer then placed in $10 \%$ formalin. Using isopropanol followed by xylene, the samples were washed and dehydrated. Before sectioning the tissue, sample was embedded with paraffin wax. The sections $(5 \mu \mathrm{m})$ were examined under the microscope by staining with Hematoxylin and Eosin stains for histological examination.

\section{Statistical analysis}

The mean of the data obtained from each group was determined and differences in the mean of each group were statically expressed in mean \pm SD. Analysis of variance (ANOVA) was performed followed by Student Newman-Keul's test to determine the significant $(p<0.05)$ difference between the groups.

\section{RESULTS}

\section{Observation of paw swelling and inflammation in MSU crystal induced Gouty arthritic rats}

Table 1 shows the results of the measurement of paw inflammation in rats. Paw swelling of rats of all the four groups was checked on everyday basis until the day of sacrifice. Paw swelling was considered as a measure of paw inflammation. Paw swelling was observed significantly higher $(p<0.05)$ in Group II rats as compared to Group I. Paw swelling in B. monnieri treated rats was observed to normalize the swelling caused by MSU crystal which was similar to the level of normal control rats. The results of $B$. monnieri were compared with that of standard drug indomethacin.

\section{Assessment of body weight of rats}

Table 1 shows the results of measurement of body weight of rats. Body weights of Group II rats were found to be reduced and compared to Group I rats. After the treatment with $B$. monnieri, the rats regained their body weight nearly to the normal level which was better than standard group.

Table 1. Results for the assessment of paw inflammation and body weight in rats.

\begin{tabular}{lccccc}
\hline Parameters & Day & $\begin{array}{c}\text { Group I (normal } \\
\text { control) }\end{array}$ & $\begin{array}{c}\text { Group II (MSU } \\
\text { induced) }\end{array}$ & $\begin{array}{c}\text { Group III (MSU + } \\
\text { Bacopa) }\end{array}$ & $\begin{array}{c}\text { Group IV (MSU + } \\
\text { Indomethacin) }\end{array}$ \\
\hline Body weight & 1st & $212 \pm 0.94$ & $180 \pm 1.37 \mathrm{~b}^{*}$ & $215 \pm 1.28 \mathrm{~b}^{*}$ & $200 \pm 1.37 \mathrm{~b}^{*} \mathrm{c}^{*}$ \\
& 2nd & $214 \pm 2.46$ & $186 \pm 1.97 \mathrm{a}^{*}$ & $219 \pm 2.03 \mathrm{a} \mathrm{b}^{*}$ & $202 \pm 1.99 \mathrm{~b}^{*}$ \\
& 3rd & $217 \pm 1.90$ & $189 \pm 1.83 \mathrm{a}^{*}$ & $223 \pm 2.34 \mathrm{a} *$ & $204 \pm 1.38 \mathrm{~b}^{*}$ \\
Paw swelling & 1st & $0.54 \pm 0.06$ & $0.94 \pm 0.09 \mathrm{a}^{*}$ & $0.60 \pm 0.03 \mathrm{~b}^{*}$ & $0.73 \pm 0.06 \mathrm{c}^{*}$ \\
& 2nd & $0.58 \pm 0.05$ & $0.89 \pm 0.02 \mathrm{a}^{*}$ & $0.61 \pm 0.02 \mathrm{a} \mathrm{b}^{*}$ & $0.69 \pm 0.06 \mathrm{a}^{*} \mathrm{~b}^{*} \mathrm{c}^{*}$ \\
& 3rd & $0.56 \pm 0.06$ & $0.98 \pm 0.01 \mathrm{a} *$ & $0.64 \pm 0.02 \mathrm{a} * \mathrm{~b}^{*}$ & $0.75 \pm 0.04 \mathrm{a}^{*} \mathrm{~b}^{*} \mathrm{c}^{*}$ \\
\hline
\end{tabular}

The values are expressed as mean \pm S.D. Six Animals in a group where comparisons represented as: a. group I vs. group II, III and IV; b. group II vs. group III and IV; c. group III vs. group IV. Statistical analysis was performed by one-way ANOVA used by Student's Newman-Kuel's test. The symbols $\left(^{*}\right)$ indicates statistical significance $(p<0.05)$ between the groups. 


\section{Effect of B. monnieri on the serum levels of liver enzyme markers in MSU crystal induced Gouty arthritic rats}

Table 2 shows the results for the assessment of serum levels of liver enzyme markers. Serum levels of liver enzyme markers in Group II rats were found to be significantly higher $(p<0.05)$ than normal. While in Group III treated rats, the alteration caused by MSU was decreased by the treatment of $B$. monnieri that was almost in normal levels on all these enzymes. Bacopa monnieri was better in normalizing the level of serum markers than the rats treated with indomethacin.

\section{Effect of B. monnieri on the antioxidant enzyme activities in MSU induced rats}

Table 2 shows the results of the evaluation of levels of antioxidant enzymes in serum, liver, and kidney samples of rats. Antioxidant enzyme levels in rats were analyzed by obtaining the samples of liver, kidney, and the serum of rats from all the four groups. The activities of antioxidant enzymes were found to be normal in Group I rats in liver, kidney, and serum. The levels of these enzymes were reduced significantly $(p<0.05)$ in Group II rats. In B. monnieri treated rats, antioxidant enzyme levels were recovered to normal from the inflammation caused by MSU crystal; this indicates the efficiency of $B$. monnieri in reducing the oxidative stress. Table 2 shows the results of lipid peroxidation levels in serum, kidney, and liver samples of rats. Lipid peroxidation levels were found significantly higher $(p<0.05)$ in liver, kidney, and serum samples of Group II, whereas in Group III, reduced levels of lipid peroxidation were found reflecting the antioxidant capacity of the test drug in treating the inflammation of MSU crystal.

\section{Results of histopathological analysis}

Figures 1 and 2 shows the results of histopathological analysis of skin and bone tissues in rat foot, respectively. Skin and bone tissues of the foot of rats from each experimental group were stained with hematoxylin and eosin and then observed under the microscope. Normal morphology of skin and bone tissues was observed in control rats (Fig. 1a and Fig. 2a). In MSU-treated rats (Fig. 1b and Fig. 2b), hemorrhage was observed in subcutaneous tissues of skin, while diminishing joint space and deformed articular cartilage was observed in bone tissues representing the arthritic effect of MSU crystals in rats. In Group III (Fig. 1c and Fig. 2c), it was found that B. monnieri was successful in recovering the normal skin morphology; joint spaces, articular cartilage also appeared normal indicating the anti-inflammatory effect of $B$. monnieri.

\section{DISCUSSION}

Inflammation of the paw by MSU crystals was found to be reduced upon administering $B$. monnieri. MSU crystal-induced paw swelling was also observed in other studies (Dinesh and Rasool, 2017). The effect of the test drug was compared with the standard drug Indomethacin. Administration of MSU crystals to Wistar rats resulted in an increase in lipid peroxide, which could be due to its release from monocytes and neutrophils during inflammation, which remained concealed in the liver of MSU treated rats due to decreased levels of hepatic cytochrome P-450 (Martin et al., 2009). The similar result of MSU crystal was also observed in other studies (Dhanasekar and Rasool, 2016). The increased levels of lipid peroxide could also be due to its release into the bloodstream from the liver, resulting in its increased levels in the serum. Increase in lipid peroxide levels resulted in a decrease of antioxidants, such as SOD, catalase, and glutathione peroxidase in the MSU crystal-treated rats. The similar activity of MSU was also observed in other studies on MSU crystal (RuizMiyazawa et al., 2018). Treatment of the rats with B. monnieri helped bring down the MSU-induced lipid peroxide levels and increase the antioxidant levels closer to the normal range. Elevated liver enzyme markers indicate inflammation or damage to the hepatocytes (Li et al., 2019). Liver enzyme markers, such as ALT, ALP, and AST were found to increase drastically in MSU crystal-induced rats which are similar to other studies (Araújo et al., 2016; Martin et al., 2009;). Administration of B. monnieri to

Table 2. Results of evaluation of levels of liver enzyme markers, lipid peroxidation and antioxidant enzymes in rats.

\begin{tabular}{|c|c|c|c|c|c|}
\hline Samples & Parameters & $\begin{array}{c}\text { Group I } \\
\text { (normal control) }\end{array}$ & $\begin{array}{c}\text { Group II } \\
\text { (MSU induced) }\end{array}$ & $\begin{array}{c}\text { Group III } \\
(\text { MSU + Bacopa })\end{array}$ & $\begin{array}{c}\text { Group IV (MSU + } \\
\text { Indomethacin) }\end{array}$ \\
\hline \multirow[t]{3}{*}{ Liver } & SOD (Units/min $/ \mathrm{mg} /$ protein) & $3.9 \pm 0.85$ & $1.34 \pm 0.62 \mathrm{a}^{*}$ & $3.54 \pm 0.18 b^{*}$ & $2.76 \pm 1.01 \mathrm{a} * \mathrm{~b}^{*} \mathrm{c} *$ \\
\hline & Catalase (Units/min/mg/protein) & $11.84 \pm 1.08$ & $4.93 \pm 0.97 \mathrm{a}^{*}$ & $10.03 \pm 0.67 \mathrm{a} * \mathrm{~b} *$ & $9.06 \pm 0.87 \mathrm{c}^{*}$ \\
\hline & LPO (Units/min/mg/protein) & $1.69 \pm 0.54$ & $2.58 \pm 0.95 \mathrm{a}^{*}$ & $1.76 \pm 1.02 \mathrm{a} * \mathrm{~b} *$ & $1.94 \pm 0.86 \mathrm{~b} * \mathrm{a} *$ \\
\hline \multirow[t]{3}{*}{ Kidney } & SOD (Units/min $/ \mathrm{mg} /$ protein) & $3.02 \pm 1.81$ & $0.95 \pm 1.87 \mathrm{a}^{*}$ & $2.95 \pm 1.7 \mathrm{a}^{*}$ & $2.15 \pm 1.94 b^{*}$ \\
\hline & Catalase (Units/min/mg/protein) & $5.94 \pm 0.77$ & $2.97 \pm 1.34 \mathrm{a}^{*}$ & $5.37 \pm 1.64 b^{*}$ & $4.62 \pm 1.64 *$ \\
\hline & LPO (Units/min/mg/protein) & $1.75 \pm 1.02$ & $3.02 \pm 2.5 \mathrm{a}^{*}$ & $1.85 \pm 2.64 \mathrm{a}^{*} \mathrm{~b} *$ & $2.01 \pm 2.04 \mathrm{~b} * \mathrm{c} *$ \\
\hline \multirow[t]{6}{*}{ Serum } & $\operatorname{ALT}(\mathrm{mg} / \mathrm{dl})$ & $60.77 \pm 1.68$ & $150.24 \pm 1.84 \mathrm{a}^{*}$ & $76.45 \pm 2.21 \mathrm{a}^{*} \mathrm{~b}^{*}$ & $80.75 \pm 1.84 b * c *$ \\
\hline & $\operatorname{ALP}(\mathrm{mg} / \mathrm{dl})$ & $89.25 \pm 1.68$ & $305.87 \pm 0.37 \mathrm{a}^{*}$ & $110.54 \pm 1.24 b^{*}$ & $145.82 \pm 1.34 \mathrm{a} * \mathrm{c} *$ \\
\hline & $\operatorname{AST}(\mathrm{mg} / \mathrm{dl})$ & $90.47 \pm 1.85$ & $210.25 \pm 1.35 \mathrm{a}^{*}$ & $150.46 \pm 1.94 b^{*}$ & $165.21 \pm 1.54 \mathrm{a}^{*} \mathrm{~b}^{*} \mathrm{c}^{*}$ \\
\hline & SOD (Units/min $/ \mathrm{mg} /$ protein) & $185.29 \pm 1.45$ & $95.15 \pm 1.09 \mathrm{a}^{*}$ & $179.28 \pm 2.91 b^{*}$ & $169.46 \pm 1.38 b^{*}$ \\
\hline & Catalase (Units/min/mg/protein) & $13.48 \pm 1.98$ & $5.09 \pm 2.34 \mathrm{a}^{*}$ & $11.37 \pm 3.84 \mathrm{a}^{*} \mathrm{~b}^{*}$ & $10.95 \pm 2.48 \mathrm{a}^{*} \mathrm{~b} * \mathrm{c} *$ \\
\hline & LPO (Units/min $/ \mathrm{mg} /$ protein) & $2.06 \pm 1.58$ & $3.83 \pm 1.38 \mathrm{a}^{*}$ & $2.01 \pm 2.15 \mathrm{a}^{*}$ & $1.69 \pm 1.64 \mathrm{a}^{*} \mathrm{~b} *$ \\
\hline
\end{tabular}

The values are expressed as mean \pm S.D. Six Animals in a group where comparisons represented as: a. group I vs. group II, III and IV; b. group II vs. group III and IV; c. group III vs group IV. Statistical analysis was performed by one-way ANOVA used by Student's Newman-Kuel's test. The symbols $(*)$ indicates statistical significance $(p<0.05)$ between the groups. 
the rats showed a significant reduction in the liver enzyme marker levels. The results were compared with Indomethacin, which also showed a considerable reduction in the liver enzyme marker levels in the MSU crystal-induced rats. A similar study using Coenzyme



Figure 1. Results of histopathological analysis of skin tissues of foot of rats. $\mathrm{H}$ and $\mathrm{E}$ stain was used to perform histological study as follows: top-left $=$ Normal control group, top-right $=\mathrm{MSU}$ induced, bottom-left $=\mathrm{MSU}$ induced + Bacopa administrated and bottom-right $=$ MSU induced + Indomethacin administrated . The changes are marked through arrow: A-inflammation and B-showing erosion articular cartilage. (a) Fragment of bone showing normal morphology (control); (b) Focal area showing erosion articular cartilage with diminished joint space (MSU), inflammation; (c) Normally appearing articular cartilage (MSU + Bacopa monnieri); and (d) Normally appearing articular cartilage (MSU + indomethacin).

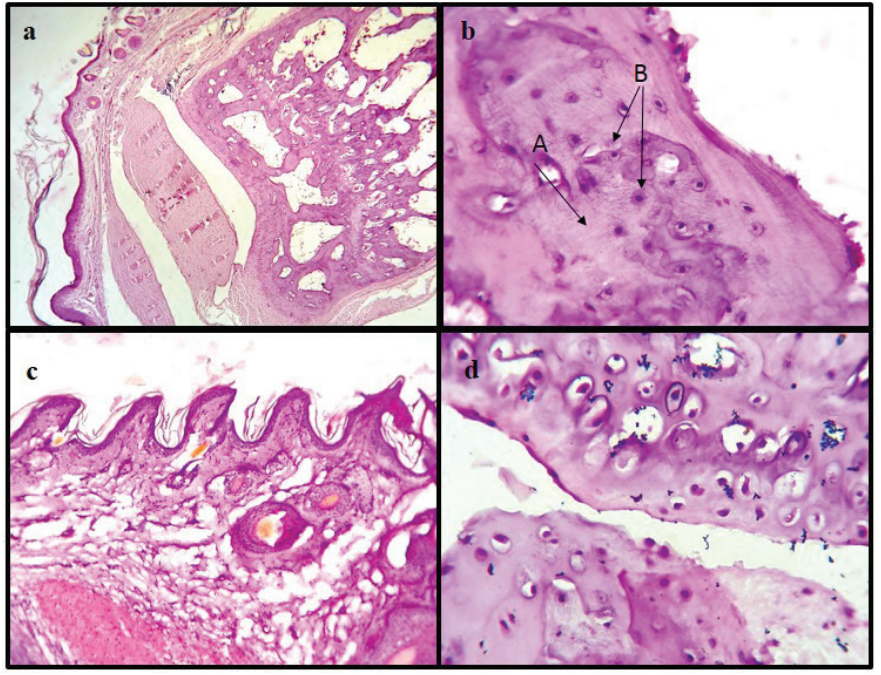

Figure 2. Results of histopathological analysis of bone tissues of foot of rats. $\mathrm{H}$ and $\mathrm{E}$ stain was used to perform histological study as follows: top-left $=$ Normal control group, top-right $=\mathrm{MSU}$ induced, bttom-left $=\mathrm{MSU}$ induced + Bacopa administrated and bottom-right $=$ MSU induced + Indomethacin administrated The changes are represented in arrow: $\mathrm{A}-$ degradation and $\mathrm{B}-$ mono nuclei. (a) Skin and adnexal structure appear normal (control); (b) subcutaneous tissue showing Hemorrhage (MSU treated); (c) Skin, adnexal structure, subcutaneous tissue showing normal morphology (MSU + Bacopa monnieri); and (d) Skin morphology appearing normal. One in subcutaneous tissue Hemorrhage (MSU + indomethacin)
Q10 as the test drug (Udhaya Lavinya et al., 2016) yielded similar results. Indomethacin has also showed similar result in other studies (Araújo et al., 2016; Martin et al., 2009). Gout is a type of arthritis that involves a defect in uric acid metabolism, resulting in accumulation of uric acid in the blood, joints, and other tissues, such as the liver and kidney. GA occurs due to the deposition of MSU in and around the joints, especially in the leukocytes of the synovial fluid (Inokuchi et al., 2006), a small part of which phagocytose the MSU crystals and release certain mediators which causes inflammation (Landis and Haskard, 2001) along with reddening of the skin and intense pain (Chia et al., 2008). The parameters used in this study include measurements of paw size, elevation in lipid peroxide, and falling antioxidant levels, along with histopathological examinations of the paws. The Subjugation of Wistar female albino rats to MSU crystals resulted in the incorporation of the crystals in the rats' paws, resulting in paw swelling due to increased lysosomal enzyme release (Habicht, 1988; Weyand, 2000). It also resulted in changes in the normal physiological and metabolic functions, which was further validated by histopathological examination of the gouty arthritic rat's foot. MSU crystal incorporation resulted in hemorrhage in the subcutaneous tissues, confirming gouty arthritis. Treatment with $B$. monnieri showed a decrease in the minimal area of erosion in joint spaces by blocking cytokines (van der Heijde, 2011), the results comparable to the effect of Indomethacin. This can be further explored to understand the mechanism of B. monnieri in treating the inflammation through the study on the metabolic pathways. The active ingredient of $B$. monnieri responsible for its potential activity can be further studied through in vivo models.

\section{CONCLUSION}

The present research has demonstrated the effect of $B$. monnieri against GA which establishes the anti-gout activity of $B$. monnieri drug. It has shown to reduce paw swelling and lipid peroxidation that has also normalized the antioxidant enzyme, liver biomarker levels, and histopathological changes. Furthermore, the molecular studies can be carried out to understand its mechanisms in treating gout.

\section{SIGNIFICANCE STATEMENT}

This study discovered the potential activity of $B$. monnieri that can be beneficial for treating arthritis induced by monosodium urate crystal. Arthritis is one of the major illnesses among people caused due to increased deposition of uric acid. The use of herbal plants in treating arthritis would help in reducing side effect which could be also cost effective. This can be studied more to understand its molecular mechanism in treating the toxicity. This study will help the researchers to uncover the critical areas of finding herbal drugs in treating arthritis and for knowing the molecular mechanism behind them which many researchers were unable to explore. Thus, a new theory on treating MSU-induced arthritis may arrive at the in vivo studies.

\section{ACKNOWLEDGMENT}

The authors would like to thank VIT for providing seed money and giving us the opportunity to work and the necessary resources to successfully carry out this work. 


\section{CONFLICTS OF INTEREST}

The authors declare that they do not have any conflicts of interest.

\section{REFERENCES}

Araújo MCPM, Ferraz-Filha ZS, Ferrari FC, Saúde-Guimarães DA. Campomanesia velutina leaves extracts exert hypouricemic effects through inhibition of xanthine oxidase and ameliorate inflammatory response triggered by MSU crystals. Rev Bras Farmacogn, 2016; 26:720-7. 2004; 9:79-85

Bacopa monniera. Monograph. Altern Med Rev J Clin Ther,

Bhansing KJ, van Bon L, Janssen M, Radstake TRDJ. Gout: a clinical syndrome illustrated and discussed. Neth J Med, 2010; 68:352-9.

Chia EW, Grainger R, Harper JL. Colchicine suppresses neutrophil superoxide production in a murine model of gouty arthritis: a rationale for use of low-dose colchicine. Br J Pharmacol, 2008; 153:128895

Chilappa CS, Aronow WS, Shapiro D, Sperber K, Patel U, Ash JY. Gout and hyperuricemia. Compr Ther, 2010; 36:3-13.

Chopra RN, Nayar SL, Chopra IC, Asolkar LV, Kakkar KK, Chakre OJ, Varma BS, Council of Scientific \& Industrial Research (India). Glossary of Indian medicinal plants; [with] Supplement. Council of Scientific \& Industrial Research, New Delhi, India, 1956.

Chowalloor PV, Keen HI. A systematic review of ultrasonography in gout and asymptomatic hyperuricaemia. Ann Rheum Dis, 2013; 72:63845 .

Chuang SY, Lee SC, Hsieh YT, Pan WH. Trends in hyperuricemia and gout prevalence: Nutrition and Health Survey in Taiwan from 19931996 to 2005-2008. Asia Pac J Clin Nutr, 2011; 20:301-8.

Dhanasekar C, Rasool M. Morin, a dietary bioflavonol suppresses monosodium urate crystal-induced inflammation in an animal model of acute gouty arthritis with reference to NLRP3 inflammasome, hypo-xanthine phospho-ribosyl transferase, and inflammatory mediators. Eur J Pharmacol, 2016; 786:116-27.

Dhawan BN. Experimental and clinical evaluation of nootropic activity of Bacopa monniera Linn. (Brahmi). Ann Natl Acad Med Sci India, 2015; 50:20-33.

Dinesh P, Rasool M. Berberine, an isoquinoline alkaloid suppresses TXNIP mediated NLRP3 inflammasome activation in MSU crystal stimulated RAW 264.7 macrophages through the upregulation of Nrf2 transcription factor and alleviates MSU crystal induced inflammation in rats. Int Immunopharmacol, 2017; 44:26-37.

Doherty M, Jansen TL, Nuki G, Pascual E, Perez-Ruiz F, Punzi L, So AK, Bardin T. Gout: why is this curable disease so seldom cured? Ann Rheum Dis, 2012; 71:1765-70.

Gubbannavar JS, Chandola HM, Harisha CR, Khanpara K, Shukla VJ. A comparative pharmacognostical and preliminary physicochemical analysis of stem and leaf of Bacopa monnieri (L.) Pennel and Bacopa floribunda (R.BR.) Wettst. Ayu, 2013; 34:95-102.

Habicht GS. Inflammation: basic principles and clinical correlates. John I. Gallin, Ira M. Goldstein, Ralph Snyderman. Q Rev Biol, $1988 ; 63: 367-8$.

van der Heijde D. Erosions versus joint space narrowing in rheumatoid arthritis: what do we know? Ann Rheum Dis, 2011; 70(Suppl 1):i116-8

Hoffmeister C, Silva MA, Rossato MF, Trevisan G, Oliveira SM, Guerra GP, Silva CR, Ferreira J. Participation of the TRPV1 receptor in the development of acute gout attacks. Rheumatol Oxf Engl, 2014; 53:240-9.

Inokuchi T, Moriwaki Y, Tsutsui H, Yamamoto A, Takahashi S, Tsutsumi Z, Ka T, Nakanishi K, Yamamoto T. Plasma interleukin (IL)-18 (interferon- $\gamma$-inducing factor) and other inflammatory cytokines in patients with gouty arthritis and monosodium urate monohydrate crystal-induced secretion of IL-18. Cytokine, 2006; 33:21-7.

Keenan RT, O'Brien WR, Lee KH, Crittenden DB, Fisher MC, Goldfarb DS, Krasnokutsky S, Oh C, Pillinger MH. Prevalence of contraindications and prescription of pharmacologic therapies for gout. Am J Med, 2011; 124:155-63.

Klemp P, Stansfield SA, Castle B, Robertson MC. Gout is on the increase in New Zealand. Ann Rheum Dis, 1997; 56:22-6.

Kongkeaw C, Dilokthornsakul P, Thanarangsarit P, Limpeanchob N, Norman Scholfield C. Meta-analysis of randomized controlled trials on cognitive effects of Bacopa monnieri extract. J Ethnopharmacol, 2014; 151:528-35.

Landis RC, Haskard DO. Pathogenesis of crystal-induced inflammation. Curr Rheumatol Rep, 2001; 3:36-41.

Ledwozyw A, Michalak J, Stepień A, Kadziołka A. The relationship between plasma triglycerides, cholesterol, total lipids and lipid peroxidation products during human atherosclerosis. Clin Chim Acta Int J Clin Chem, 1986; 155:275-83.

Li H, Ou G, He Y, Ren L, Yang X, Zeng M. Resveratrol attenuates the MSU crystal-induced inflammatory response through the inhibition of TAK1 activity. Int Immunopharmacol, 2019; 67:62-8.

Marklund S, Marklund G. Involvement of the superoxide anion radical in the autoxidation of pyrogallol and a convenient assay for superoxide dismutase. Eur J Biochem, 1974; 47:469-74.

Martin WJ, Herst PM, Chia EW, Harper JL. Sesquiterpene dialdehydes inhibit MSU crystal-induced superoxide production by infiltrating neutrophils in an in vivo model of gouty inflammation. Free Radic Biol Med, 2009; 47:616-21.

Mukherjee GD, Dey CD. Clinical trial on Brahmi. I. J Exp Med Sci, 1966; 10:5-11

Nadkarni KM, Nadkarni AK. Dr. K. M. Nadkarni’s Indian Materia medica. Popular Prakashan, Mumbai, India, 1976.

Neale C, Camfield D, Reay J, Stough C, Scholey A. Cognitive effects of two nutraceuticals Ginseng and Bacopa benchmarked against modafinil: a review and comparison of effect sizes. Br J Clin Pharmacol, $2013 ; 75: 728-37$

Neogi T. IL-1 Antagonism in acute gout: is targeting a single cytokine the answer? Arthritis Rheum, 2010; 62:2845-9.

Richette P, Bardin T. Gout. Lancet, 2010; 375:318-28.

Roubenoff R, Klag MJ, Mead LA, Liang KY, Seidler AJ, Hochberg MC. Incidence and risk factors for gout in white men. JAMA, 1991; 266:3004-7.

Ruiz-Miyazawa KW, Borghi SM, Pinho-Ribeiro FA, StaurengoFerrari L, Fattori V, Fernandes GSA, Casella AM, Alves-Filho JC, Cunha TM, Cunha FQ, Casagrande R, Verri WA. The citrus flavanone naringenin reduces gout-induced joint pain and inflammation in mice by inhibiting the activation of NFKB and macrophage release of IL-1 $\beta$. J Funct Foods, 2018; 48:106-16.

Schlesinger N. Difficult-to-treat gouty arthritis: a disease warranting better management. Drugs, 2011; 71:1413-39.

Schlesinger N, De Meulemeester M, Pikhlak A, Yücel AE, Richard D, Murphy V, Arulmani U, Sallstig P, So A. Canakinumab relieves symptoms of acute flares and improves health-related quality of life in patients with difficult-to-treat Gouty Arthritis by suppressing inflammation: results of a randomized, dose-ranging study. Arthritis Res Ther, 2011; $13: R 53$ 47:389-94.

Sinha AK. Colorimetric assay of catalase. Anal Biochem, 1972;

So A, De Meulemeester M, Pikhlak A, Yücel AE, Richard D, Murphy V, Arulmani U, Sallstig P, Schlesinger N. Canakinumab for the treatment of acute flares in difficult-to-treat gouty arthritis: Results of a multicenter, phase II, dose-ranging study. Arthritis Rheum, 2010; 62:3064 76.

Tykarski A. Evaluation of renal handling of uric acid in essential hypertension: hyperuricemia related to decreased urate secretion. Nephron, 1991; 59:364-8.

Udhaya Lavinya B, Bardhan I, Evan Prince S. Efficacy of CoenzymeQ10 in inhibiting monosodium urate crystal-induced inflammation in rats. Eur J Pharmacol, 2016; 791:589-94. 
Weyand CM. New insights into the pathogenesis of rheumatoid arthritis. Rheumatol Oxf Engl, 2000; 39(Suppl 1):3-8.

Zaka R, Williams CJ. New developments in the epidemiology and genetics of gout. Curr Rheumatol Rep, 2006; 8:215-23.

Zhang W, Doherty M, Bardin T, Pascual E, Barskova V, Conaghan P, Gerster J, Jacobs J, Leeb B, Lioté F, McCarthy G, Netter P, Nuki G, PerezRuiz F, Pignone A, Pimentão J, Punzi L, Roddy E, Uhlig T, ZimmermannGòrska I, EULAR Standing Committee for International Clinical Studies Including Therapeutics. EULAR evidence based recommendations for gout. Part II: Management. Report of a task force of the EULAR Standing Committee for International Clinical Studies Including Therapeutics (ESCISIT). Ann Rheum Dis, 2006; 65:1312-24.

Zhang Q, Gao F, Sun W, Ma J, Cheng L, Li Z. The diagnostic performance of musculoskeletal ultrasound in gout: a systematic review and meta-analysis. PLoS One, 2018; 13
Zhu Y, Pandya BJ, Choi HK. Prevalence of gout and hyperuricemia in the US general population: the National Health and Nutrition Examination Survey 2007-2008. Arthritis Rheum, 2011; 63:3136-41.

How to cite this article:

Simon JP, Gaopande PS, Praveen S, Reeja AA, Rajasekar A, Vidya R, Kumari U, Sabina EP. Influence of Bacopa monnieri in suppressing the arthritis induced by MSU crystal in Wistar albino female rats: Through biochemical and histopathological approach. J Appl Pharm Sci, 2019; 9(10):017-023. 